\title{
Risiko dan Kinerja Bank Perkreditan Rakyat: Studi Perbandingan Antara BPR Syariah dengan Konvensional di Indonesia
}

\author{
Sutrisno \\ Universitas Islam Indonesia \\ sutrisno@uii.ac.id
}

\begin{abstract}
The aims of this study were to examine the effect of risks consisting of credit risk (NPL/NPF), capital risk (CAR), liquidity risk (LDR/FDR), and operating risk (OEOI) on rural banking performance as measured by return on assets $R O A$ ), the differences in risk and performance of Islamic Rural Banking (IRB) and Conventions Rural Banking (CRB). The population is all banking in Indonesia whether operating in Islamic or conventionally with purposive sampling method. The results showed that NPL in CRB had not significant effect, while NPF IRB had negative significant effect on performance. In contrast, CAR on Islamic Rural Banks had not significant effect, while CAR of conventional rural banking has positive significant effect on performance. Liquidity risks (LDR/ $F D R$ ), both IRB and CRB have positive significant impact on performance. While the operational risk (OEOI) has a negative significant effect on the performance of $C R B$ as well as IRB. Differential test results indicate that there are significant differences between CRB and IRB in terms of profitability (ROA), credit risk (NPL / NPF), liquidity risk (LDR / FDR) risk, and operating risk (BOPO).
\end{abstract}

Keywords: Risk, Return, CAR, NPF, FDR

\section{Abstrak}

Tujuan penelitian ini adalah menguji pengarub risiko yang terdiri dari risiko kredit (NPL/NPF), risiko permodalan (CAR), risiko likuiditas (LDR/FDR), dan risiko operasi (BOPO) terhadap kinerja rural banking yang diukur dengan return on assets (ROA), perbedaan risk and performance BPRS dan BPR Konvensional. Populasi penelitian ini seluruh BPR di Indonesia baik syariah maupun konvensional dengan metode purposive sampling. Hasil penelitian menunjukkan bahwa NPL pada BPR konvensional tidak berpengarub signifikan, NPF BPR syariah berpengarub negative signifikan terbadap kinerja. Sebaliknya CAR pada BPR syariah tidak berpengarub signifikan, CAR BPR konvensional berpengarub positif signifikan terhadap kinerja. Risiko likuiditas (LDR/FDR) baik BPR konvensional maupun BPR syariah berpengarub positif signifikan terhadap kinerja. Sementara risiko operasi (BOPO) berpengarub negative signifikan terhadap kinerja BPR konvensional maupun BPR syariah. Hasil uji beda menunjukkan terdapat perbedaan signifikan antara BPR konvensional dan BPR syariah dari segi profitabilitas (ROA), risiko kredit (NPL/NPF), risiko permodalan (CAR,) risiko likuiditas ( $L D R / F D R$ ), dan risiko operasi (BOPO).

Kata Kunci: Risk, Return, CAR, NPF, FDR

Permalink/DOI:http://dx.doi.org/10.18326/infsl3.v11i2.309-328 


\section{Pendahuluan}

Menurut Undang-Undang No. 10 tahun 1998 tentang Pokok-Pokok Perbankan, yang dimaksud dengan bank adalah badan usaha yang menghimpun dana dari masyarakat dalam bentuk simpanan dan menyalurkannya kepada masyarakat dalam bentuk kredit dan atau bentuk-bentuk lainnya dalam rangka meningkatkan taraf hidup rakyat banyak. Undang-Undang No. 10 tahun 1998 juga menegaskan bahwa perbankan dikelompokkan ke dalam bank umum dan bank perkreditan rakyat. Seperti yang tercantum dalam pasal 1 ayat 2 dan ayat 3 bahwa Bank Umum adalah bank yang melaksanakan kegiatan usaha secara konvensional dan atau berdasarkan Prinsip Syariah yang dalam kegiatannya memberikan jasa dalam lalu lintas pembayaran, sedangkan Bank Perkreditan Rakyat adalah bank yang melaksanakan kegiatan usaha secara konvensional atau berdasarkan Prinsip Syariah yang dalam kegiatannya tidak memberikan jasa dalam lalu lintas pembayaran. Konsep operasional bank di Indonesia juga dipisahkan ke dalam dua jenis yakni bank konvensional yang menggunakan instrumen bunga dan bank syariah yang dalam operasionalnya tidak diijinkan menggunakan syariah tetapi berdasarkan prinsip syariah.

Bank merupakan very regulated company yakni institusi yang dalam operasionalnya sangat diatur oleh pemerintah. Hal ini disebaabkan karena aset bank mayoritas dari masyarakat, sehingga jika ada bank yang dilikuidasi akan berdampak merugikan masyarakat, sehingga bisa menurunkan kepercayaan masyarakat. Pemerintah melalui Otoritas Jasa Keuangan (OJK) mengatur mulai dari Direksi dan komisaris bank yang harus melalui fit and proper test oleh OJK, pangaturan kesehatan bank, pengaturan tentang permodalan dan kredit yang diberikan, net open position, dan aturan lainnya. Oleh karena itu, bank merupakan perusahaan yang mempunyai risiko tinggi. Seperti diungkapkan oleh Brigham dan Ehrhard (2009) bahwa ada hubungan positif antara risiko dan kinerja, artinya jika risikonya tinggi sudah selayaknya akan memperoleh keuntungan yang tinggi. 
Dalam UU No. 10 tahun 1998 risiko bank terdiri dari risiko kredit, risiko likuiditas, risiko investasi, risiko operasi, risiko penyelewengan, risiko tingkat bunga, risiko fidusia, risiko solvensi, risiko valuta asing, dan risiko persaingan. Sangat banyak risiko yang dihadapi oleh bank sehingga diperlukan manajemen yang tangguh untuk mengelola sebuah bank. Kredit atau pembiayaan yang diberikan harus dikelola dengan baik karena menjadi pendapatan utama bank, yang jika tidak dikelola dengan baik, bisa menimbulkan kerugian jika banyak kredit yang bermasalah atau non performing loan. Rsiko kredit (NPL/NPF) akan menurunkan keuntungan bank karena risiko ini akan menjadi biaya. Temuan Mahmud et al (2016) menunjukkan risiko kredit (NPL) berpengaruh negatif terhadap profitabilitas. Demikian pula dengan Yusuf dan Mahrianan juga menemukan NPF berpengaruh negatif terhadap profitabilitas.

Likuiditas merupakan aspek yang sangat penting karena ini menyangkut keamanan dana masyarakat. Likuiditas bisa diukur dengan loan to deposit ratio (LDR) yakni besarnya dana masyarakat yang diberikan untuk kredit. Semakin besar semakin berisiko. Wahdan dan El-Leithy (2017) dan Bukhari dan Qudus (2012) menemukan pengaruh yang positif risiko likuiditas (LDR) dengan perofitabilitas. Yusuf dan Mahriana (2016) yang meneliti pada Bank Pembiayaan Rakyat Syariah (BPRS) di aceh juga menemukan FDR berpengaruh positif terhadap profitabilitas.

Modal bank bermafaat sebagai dana cadangan untuk menutup risiko bank jika mengalami kerugian. Modal bank diukur dengan capital adequacy ratio (CAR) yang telah ditetapkan oleh pemerintah (OJK) dengan nilai minimum 8\%. Semakin tinggi CAR semakin baik dan mampu meningkatkan keuntungan. Hasil penelitian Idris et al (2011) menemukan pengaruh antara risiko permodalan (CAR) dengan profitabilitas. Hallunovi dan Kume (2016), Vong dan Chan (2009), dan Syafri (2012) menemukan pengaruh positif antara permodalan (CAR) dengan profitabilitas.

Efisiensi merupakan kunci sukses bagi bank, sehingga bank harus dikelola dengan efisien. Dalam operasionalnya manajemen bank dihadapkan pada risiko operasi yang dikur dengan rasio biaya operasi dengan pendapatan operasi (BOPO). Semakin tinggi 
BOPO menunjukkan risiko operasi semakin tinggi, dan akan menurunkan tingkat keuntungan bank. Hasil penelitian Hallunovi dan Kume (2016) dan Sudiyatno (2010) menemukan pengaruh negatif BOPO terhadap profitabilitas. Demikian pula dengan hasil penelitian Abdillah et al (2016) di Indonesia juga menemukan pengaruh negatif antara BOPO dengan profitabilitas.

Seperti diungkapkan di muka bahwa bank berdasar fungsinya terbagi ke dalam bank umum dan Bank Perkreditan Rakyat (BPR). BPR merupakan bank yang menjalankan fungsi intermediary tetapi tidak diijinkan melakukan transaksi lalu lintas pembayaran. Sama dengan bank umum, operasional BPR juga terdiri dari dua konsep. Operasional BPR konvensional menggunakan instrumen bunga sementara BPR syariah tidak menggunakan instrumen bunga tetapi beroperasi sesuai dengan ketentuan syariah. Dengan konsep operasional yang berbeda, menjadikan risiko dan kinerja yang berbeda pula. Hassene dan kais (2016) melakukan penelitian perbedaan kinerja bank konvensional dan bank syariah di Malaysia. Demikian pula dengan Moin (2008) dan Latif et al (2016) meneliti perbedaan kinerja bank syariah dan konvensional di Pakistan.

\section{Kajian Teori}

\section{Risiko Kredit dan Kinerja}

Sumber utama pendapatan bank termasuk BPR berasal dari bunga atau bagi hasil yang diperoleh dari kredit atau pembiayaan yang diberikan (Rivai et.al, 2009). Semakin besar kredit yang disalurkan akan memberikan sumbangan pendapatan yang besar. Kredit/pembiayaan yang diberikan merupakan sumber utama pendapatan jika dikelola dengan dengan prinsip perkreditan, tetapi juga memunculkan risiko jika tidak dikelola dengan baik yakni berpotensi menimbulkan kerugian yang disebabkan gagal bayar. Kredit bermasalah ini akan menurunkan tingkat keuntungan karena akan secara akuntansi akan diperlakukan biaya. Risiko kredit dalam perbankan diukur dengan non-performing loan (NPL) bagi bank konvensional dan non-performing financing (NPF) bagi bank syariah. Semakin tinggi kredit yang bermasalah akan menurunkan tingkat keuntungan BPR. Menurut Yusuf dan Mahriana (2013) terdapat pengaruh negatif dan signifikan NPF di 
BPRS Aceh terhadap ROA. Demikian pula dengan Akhtar et.al (2011) di Pakistan dan Zeitun (2012) yang meneliti bank syariah di Arab juga menemukan pengaruh yang negatif dan signifikan. Vong dan Chan (2009) dan Syafri (2012) juga menemukan pengaruh negatif dan signifikan antara NPL dengan kinerja bank konvensional.

\section{Risiko Permodalan dan Kinerja}

Sumber dana bank sebagian besar berasal dari masyarakat dan hanya sebagian kecil yang bersumber dari pemilik (modal sendiri). Oleh karena itu pemerintah menentukan batas minimum modal sendiri yang harus dimiliki. Permodalan bank sangat penting karena berfungsi untuk memback-up risiko kerugian yang dihadapi oleh bank. Permodalan bank yang diukur dengan capital adequacy ratio (CAR), oleh pemerintah diatur minimum sebesar 8\%. Semakin tinggi CAR semakin menunjukkan semakin baik bank. Margaretha dan Zai (2013) yang meneliti perbankan di Indonesia menemukan pengaruh yang positif antara CAR dengan kinerja bank. Almazari (2014) dan Abdillah et.al (2011) juga menemukan pengaruh yang positif antara permodalan dengan kinerja bank.

\section{Risiko Likuiditas Dan Kinerja}

Bisnis bank adalah kepercayaan artinya bank yang baik adalah yang dipercaya oleh masyarakat. Untuk menjaga kepercayaan masyarakat, bank harus menyediakan dana yang cukup agar bisa memenuhi pengambilan dana masyarakat yang sewaktu-waktu diambil. Likuiditas merupakan kemampuan bank dalam memenuhi kewajiban jika ada masyarakat yang mengabil dananya sewaktu-waktu. Salah satu ukuran likuidtas adalah loan to deposit ratio (LDR) yakni perbandingan antara kredit yang diberikan dengan dana masyarakat. Semakin besar LDR semakin besar kredit yang diberikan sehingga akan meningkatkan pendapatan bunga yang akhirnya akan meningkatkan profitailitas. Margaretha dan Zai (2013) menemukan LDR pengaruh yang positif dan signifikan terhadap kinerja bank. Yusuf dan Mahriana (2016) juga menemukan pengaruh yang signifikan dan positif antara FDR dengan profitabilitas di BPR syariah. Demikian pula Almazari (2014) juga menemukan pengaruh postif antara LDR dengan kinerja bank. 


\section{Risiko manajemen dan kinerja}

Usaha utama bank adalah memberikan kredit atau pembiayaan dengan sumber dana dari masyarakat. Manajemen bertugas untuk menyalurkanya dengan tingkat kinerja yang tinggi dan menekan biaya dananya. Risiko manajemen terjadi jika pendapatan laba operasi dibanding dengan pendapatan operasi semakin menurun yang menunjukkan tidak efisiennya manajemen .Risiko manajemen sering diproksikan dengan net interest margin (NIM) atau net profit margin (NPM) yakni perbandingan antara pendapatan bunga dengan kredit yang diberikan. Semakin tinggi NIM atau NPM semakin baik sehingga diharapkan bisa meningkatkan kinerjanya. Margaretha dan Zai (2013) menemukan pada perbankan di Indonesia NIM berpengaruh signifikan dan positif terhadap kinerja bank. Purwoko dan Sudiyatno (2013) juga menemukan hal yang sama. Demikian pula dengan Ongore dan Kusa (2013) yang melakaukan penelitian di Kenya juga menemukan NIM berpengaruh positif terhadap kinerja bank.

\section{Risiko Operasi dan Kinerja}

Persaingan BPR yang semakin ketat yang tidak hanya bersang dengan dengan sesame BPRkonvensional tetapi juga BPR syariah, mendorong manajemen bank untuk beroperasi efisien. Efisiensi bank akan menurunkan risiko operasi yang diukur dengan rasio biaya operasi dengan pendapatan operasi. Manajemen bank harus bisa mengelola biaya overhead bank untuk bisa menekan membengkaknya bisaya operasi dan bisa menyalurkan kredit atau pembiayaan dengan spread yang tinggi. Semakin tinggi BOPO menunjukkan risiko operasi semakin tinggi sehingga bisa menurunkan tingkat keuntungan bank. Harjanti et al (2016) yang meneliti BPR di Jawa tengah menemukan variabel BOPO berpengaruh secara signifikan dan negatif terhadap profitabilitas bank. Sudiyatmo (2012) dan Syafri (2010) juga menemukan pengaruh yang signifikan dan negatif antara risiko operasi dengan kinerja bank. Demikian juga dengan temuan Nisar et al (2015) dan Akhtar et al (2011). 


\section{Perbedaan Risiko Dan Kinerja Bank}

Operasional perbankan di Indonesia dibagi menjadi dua konsep yakni konsep bunga dan konsep syariah. Kosep bunga diaplikasikan pada perbankan konvensional sedangkan konsep syariah yang tidak dibolehkan menggunakan instrumen bunga diaplikasikan pada bank syariah. Bagi bank konvensional yang menggunakan konsep bunga, aplikasinya lebih mudah karena semua produk baik pendanaan maupun pembiayaan menggunakan instrumen bunga, sedangkan bank syariah harus sesuai dengan prinsip syariah yang lebih rumit. Dengan adanya perbedaan ini kemungkinan besar akan berpengaruh terhadap kinerja bank baik tingkat keuntungan maupun risikonya. Instrumen likuidtas bank syariah masih sangat minim, karena sebagian instrumen likuidtas berbasais bunga. Sejalan dengan itu Moin (2008) menemukan bank syariah di Pakistan mempunyai likuditasnya tinggi tetapi masih kurang menguntungkan.

Youssef dan Samir (2015) yang membandingkan perbedaan kinerja bank syariah dan konvensional di Mesir menemukan risiko permodalan (CAR), risiko kredit (NPL), dan risiko likuditas (LDR) berbeda antar kedua bank. Milhem dan Istaiteyeh (2015) menemukan perbedaan CAR dan kinerja baik ROA maupun ROE antara bank syariah dan bank konvensional di Jordan, sedangkan LDR, BOPO tidak ada perbedaan. Masruki et al (2010) menemukan ada perbedaan antara bank syariah dengan bank konvensional baik dari sisi profitailitas, likuiditas dan efisiensi. Dengan demikian bisa dihupotesiskan sebagai berikut:

\section{Metode Penelitian}

\section{Data Penelitian}

Populasi penelitian adalah semua Bank Perkreditan Rakyat (BPR) baik yang beroperasi secara konvensional maupun syariah. Samepl yang diambil sebanyak 53 BPR konvensional, dan 55 BPR syariah dari 50 sampel yang direncanakan. Pengambilan sampel dilakukan dengan purposive sampling yakni yang mempunyai data lengkap sesuai yang dibutuhkan. Data dikumpulkan adalah data kuartalan selama dua tahun (2015 dan 2016). Dengan demikian 
data yang terkumpul untuk dianalisis adalah BPR konvensional sebanyak 424 data dan BPR syariah sebanyak 440 data. Pengambilan data dilakukan langsung website Bank Indonesia.

\section{Variabel Penelitian}

Variabel terdiri dari variabel dependen yakni kinerja BPR yang diukur dengan ROA dan variabel independen terdiri dari risiko kredit/pembiayaan, risiko permodalan, risiko likuiditas, dan risiko operasi.

\section{Analisis Data}

Ada dua alat analisis untuk menguji hipotesis yang diajukan yakni analisis regresi berganda dan uji beda independent sample t-test. Adapun analisis regresi berganda adalah sebagai berikut:

Bank Konvensional :

$\mathrm{ROA}=\beta_{0}+\beta_{1} \mathrm{NPL}+\beta_{2} \mathrm{CAR}+\beta_{3} \mathrm{LDR}+\beta_{4} \mathrm{BOPO}$

Bank Syariah

$$
\mathrm{ROA}=\beta_{0}+\beta_{1} \mathrm{NPF}+\beta_{2} \mathrm{CAR}+\beta_{3} \mathrm{FDR}+\beta_{4} \mathrm{BOPO}
$$

\section{Hasil Penelitian}

\section{Statistik Deskriptif}

Kinerja BPR yang diukur dengan ROA menunjukkan BPR konensional rata-rata sebesar $4.08 \%$ lebih tinggi dibanding BPR syariah dengan rata-rata $3.00 \%$, tetapi variasi ROA BPR syariah sangat tinggi sebab ada nilai minimum sebesar $-13.75 \%$ dan maksimum sebesar 202.00\%. Risiko kredit (NPL) BPR konvensional sudah bagus dengan rata-rata sebesar 3.82\% dibawah ketentuan maksimum 5\%, sementara rata-rata risiko pembiayaan (NPF) BPR syariah sebesar 7,89\% jauh diatas ketentuan maksimum, sehingga bisa diartikan bahwa kualitas pembiayaan bank syariah masih buruk.

Dari sisi kecukupan permodalan, BPR konvensional memiliki nilai rata-rata 19,09\% dan BPR syariah sebesar 24,09\%, Dari sisi kesehatan bank kondisi CAR tersebut sangat sehat tetapi dari sisi efisiensi kurang bagus karena ketentuan minimumnya sebesar $8 \%$, sehingga manajemen belum bisa memanfaatkan mpdal bank untuk disalurkan ke masyarakat. 
Variabel likuiditas yang diukur dengan LDR/FDR menunjukkan BPR konvensional mempunyai nilai rata-rata 81,70\% sedangkan BPR syariah sebesar 96,09\%. Angka ini menunjukkan rata-rata likuditas BPR sudah baik karena tidak melebihi $100 \%$, tetapi ada BPR syariah yang risiko likuditasnya sangat tinggi mencapai 384,01\%. Kondisi ini sangat buruk bagi kesehatan bank karena sangat rentan terhadap penarikan dana masyarakat.

Risiko operasi yang dikur dengan BOPO menunjukkan BPR konvensional nilai rata-rata sebesar $78.70 \%$ dan BPR syariah $55,41 \%$, sehingga BPR syariah lebih efisien dalam mengelola biaya operasinya. Namun demikian variasi BOPO BPR syariah sangat tinggi yang ditunjukkan nilani maksimumnya sebesar $198.81 \%$ dan minimumnya $20,57 \%$.

\section{Hasil uji hipotesis pertama (uji t)}

Berdasarkan hasiluji t dengan menggunakan taraf signifikansi 0.05 , ditemukan bahwa variabel NPL pada bank konvensional berpengaruh negatif tetapi tidak signifikan terhadap kinerja BPR, sementara bagi BPR syariah NPF berpengaruh negatif dan signifikan terhadap kinerja. Risiko permodalan yang diukur dengan CAR bagi BPR konvensional berpengaruh positif dan signifikan terhadap kierja bank syariah, sementara pada BPR syariah CAR berpengaruh positif tetapi tidak signifikan terhadap kinerja BPR.

Risiko likuiditas (LDR) BPR konvensional menghasilkan nilai signifikansi sebesar 0.025 lebih kecil dengan yang didyaratkan sehingga LDR berpengaruh positif dan signifikan terhadap kinerjanya, demikian pula dengan FDR BPR syariah juga berpengaruh positif dan signifikan terhadap kinerja (ROA), karena nilai signifikansinya lebih kecil dibanding yang disyaratkan. Risiko operasi (BOPO) bagi BPR konvensional berpengaruh negatif dan signifikan terhadap ROA karena lebih kecil dari yang disyaratkan. Begitu juga dengan BOPO BPR syariah juga berpengaruh negatif dan signifikan.

Untuk menguji hipotesis perbedaan risiko dan kinerja antara BPR konvensional dengan BPR syariah, digunakan alat analisis Independend sample t test. Rata-rata ROA BPR konvesnional 
lebih tinggi dibanding bank syariah, sementara rata-risiko kredit atau pembiayaan lebih tinggi bank syariah. Hal ini mendikasikan risiko pembiayaan BPR syariah lebih tinggi karena pembiayaan bermasalah tinggi mengakibatkan kinerjanya juga kurang bagus dibanding BPR konvensional.

Kecukupan modal BPR syariah memiliki rata-rata jauh lebih lebih tinggi dibanding BPR konvensional, menunjukkan BPR syariah masih sangat sulit untuk mengendalikan modalnya agar efisien. Sementara risiko likuiditas BPR syariah lebih tinggi dibanding BPR konvensional. Sedangkan dari risiko operasi (BOPO) rata-rata BPR syariah jauh lebih kecil dibanding BPR konvensional

Dari uji beda dengan independend sample t test diperoleh hasil bahwa terdapat perbedaan yang signifikan antara kinerja (ROA) BPR konvensional dengan BPR syariah, karena nilai signifikansinya 0,033 lebih kecil dari 0.05. Risiko kredit (NPL/NPF) dan risiko permodalan (CAR) juga secara signifikan berbeda antara BPR syariah dan BPR konvensional. Demikian juga dengan risiko likuiditas (LDR/FDR) dan risiko operasi (BOPO) berbeda signifikan karena menghasilkan nilai signifikansi sebesar 0.000 lebih kecil dibanding yang disyaratkan.

\section{Risiko Kredit dan Kinerja}

Risiko kredit/pembaiayaan baik BPR konvensional maupun syariah mempunyai pengaruh negatif artinya jika NPL atau NPF BPR naik akan menurunkan kinerja BPR yang diukur dengan ROA. NPL/ NPF merupakan potensi kerugian bagi BPR karena jika sebgaian NPL harus dicadangkan sebagai biaya sehingga akan mengurangi tingkat keuntungannya. Pemerintah mengatur batas maksimum NPL/NPF ini sebesar 5\%, jika melebihi ketentuan tersebut, maka nilai kesehatan bank akan turun.

Risiko kredit (NPL) BPR konvensional berpengaruh negatif tetapi tidak signifikan, artinya walaupun sudah arah hubungan sudah sesuai dengan hipotesis tetapi pada bank konvesnional besar kecilnya NPL tidak mempengaruhi kinerja. Hal ini disebabkan manajemen BPR konvensional bisa mengendalikan NPL, sehingga tidak melebihi batas maksimum yang disyaratkan. 
Data menunjukkan bahwa NPL BPR konvensional rata-rata sebesar 3.82\% dan variasinya juga tidak terlalu tinggi, sehingga tidak berpengaruh pada kinerja BPR. Hasil ini sesuai dengan peneltian Mahmud et.al. (2016) di Pakistan yang menemukan NPL tidak berpengaruh terhadap kinerja bank. Demikian juga dengan Harjanti et.al (2016) yang meneliti BPR konvensional di Tegal juga menemukan NPL tidak berpengaruh terhadap kinerja bank.

Sebaliknya risiko pembiayaan (NPF) BPR syariah mempunyai pengaruh yang signifikan terhadap kinerja, karena NPF BPR syariah sangat bervariasi bahkan nilai rata-rata mencapai $7.88 \%$ jauh diatas ketentuan maksimal. Temuan ini sesuai dengan hasil penelitian Yusuf dan Mahriana (2016) pada BPR syariah di Aceh. Demikian pula dengan Abdilah et.al (2016) dan Akhtar et.al (2011) yang meneliti Bank syariah di Pakistan juga menemukan pengaruh negatif dan signfikan terhadap kinerja.

\section{Risiko Permodalan dan Kinerja}

Risiko permodalan yang diukur dengan rasio kecukupn modal (CAR) dan pengaruhnya terhadap kinerja bank menunjukkan untuk BPR konvensional berpengaruh positif dan signifikan, artinya semakin tinggi CAR akan semkin meningkatkan kinerjanya. Pemerintah mengatur kecukupan permodalan bank minimum sebesar 8\% dengan maksud jika terjadi kerugian, pemilik harus menanggung dengan modal yang disetorkannya. Nilai rata-rata CAR konvesional sebesar $19.09 \%$, tetapi variasinya cukup tinggi dimana nilai minimumnya sebesar $4,32 \%$ dibawah ketentuan minimum dengan maksimum 55.04\%. Tingginya CAR akan menambah kepercayaan masyarakat terhadap bank. Oleh karena itu semakin tinggi CAR masyarakat akan semakin menyukai karena risikonya lebih kecil, semakin banyak nasabah akan meningkatkan kinerja bank. Youssef dan Samir (2015) di Mesir dan (Mahmud et.at (2016) di Bangladesh juga menemukan CAR berpengaruh positif dan signifikan terhadap kinerja bank. Demikian pula dengan Milhelm dan Istaiteyeh (2015) dan Sanwari dan Zakaria (2013) menemukan pegaruh yang positif dan signifikan antara CAR dengan ROA. Di Indonesia penelitian Sudiatno (2010) menemukan hal yang sama. 
Pada BPR syariah ternyata ditemukan hasil yang berbeda, yakni CAR berpengaruh positif tetapi tidak signifikan. Temuan ini dimungkinkan karena CAR BPR syariah sangat tinggi, sehingga masyarakat sudah tidak khawatir dengan kecukupan modal bank. Rata-rata CAR BPR syariah sangat tinggi sebesar $24.10 \%$ jauh diatas ketentuan CAR mimum 8\%. Karena tingginya CAR BPR syariah sehingga masyarakat sudah sangat percaya pada BPR syariah dan akibatnya tidak mempengaruhi kinerja BPR syariah. Hasil ini sesuai dengan temuan Harjanti et.al (2016) yang menemukan CAR tidak berpengaruh pada kinerja BPR di Tegal. Idris et.al (2011) juga menemukan CAR tidak berpengaruh terhadap ROA.

\section{Risiko Likuiditas dan Kinerja}

Likuditas yang diukur dengan lona to deposit ratio (LDR) bagi BPR konvensional dan financing to deposit ratio (FDR) bagi BPR syariah terbukti berpengaruh positif dan signifikan baik pada BPR konvensional maupun BPR syariah. Hal ini menunjukkan semakin tingginya krdit ataua pembiayaan akan semakin meningkatkan profitabilitas BPR. Kredit atau pembiayaan yang diberikan oleh bank merupakan penghasilan utama bagi perbankan, sehingga dengan semakin tingginya kredit atau pembiayaan mempunyai perluang meningkatkan keuntungan bank jika pengelolaan kredit/ pembiayaan tersebut baik. LDR pada BPR konvensional dan FDR pada BPR syariah menunjukkan angka yang optimal artinya ada diantara batas atas dan batas bawah yang disaratkan oleh OJK yakni antara $80 \%$ sampai $100 \%$. BPR konvensional mempunyai LDR rata-rata sebesar $81.70 \%$ sementara BPR syariah sebesar $96.09 \%$. Dengan angka sebesar itu, seharunya ROA BPR syariah lebih tinggi karena penghasilannya lebih tinggi, tetapi karena NP BPR sariah juga sangat tinggi mengakibatkan ROA BPR syariah lebih rendah.

Hasil penelitian ini sejalan dengan temuan Yusuf dan Mahrianan (2016) yang meneliti pada BPR syariah di Aceh. Youssef dan Samir (2015) juga menemupkan pengaruh yang positif dan signifikan antara FDR terhadap kinerja bank syairah di Mesir. Demikian pula dengan Sanwari dan Zakaria (2013) dan Siad dan Tumin (2011) juga menemukan pengaruh yang signifikan antara FDR dengan ROA. 


\section{Risiko operasi dan kinerja}

Hipotesis dari risiko operasi (BOPO) juga terbukti yakni berpengaruh negatif dan signifikan terhadap kinerja BPR baik konvensional maupun BPR syariah. Hasil ini mengandung arti semakin rendah $\mathrm{BOPO}$ akan meningkatkan profitabilitas bank. BOPO merupakan perbandingan antara biaya operasi dengan penghasilan operasi, semakin rendah BOPO semakin efisien bank dalam operasinya. Dilhat dari BOPO, BPR syariah menunjukkan rata-rata $\mathrm{BOPO}$ sebesar $55.41 \%$ artinya sangat efisien, dan $\mathrm{BOPO}$ BPR konvensional rata-rata sebesar $78.7 \%$ masih efisien. Manajemen harus bisa mengendalikan risiko operasi ini karena BOPO sebagai pengurang penghasilan, sehingga jika ada kenaikan BOPO akan menurunkan profitabiltas. Manajemen harus bisa mengndalikan biaya utama dalam BOPO yakni bunga simpanan atau bagi hasil dan biaya sumber daya manusia. Kedua biaya ini harus bisa dikendalikan oleh manajemen agar menurunkan BOPO.

Hasil ini sesuai dengan temuan Akhtar et.al (20110) yang melakukan penelitian di Pakistan. Harjanti et.al (2016) yang meneliti BPR syariah di Tegal juga menemukan pengaruh negatif dan signifikan antara BOPO dengan kiernaja bank. Syafri, (2012) dan Sudiatmo (2010) juga menemukan pengaruh negatif dan signifkan antara BOPO dengan kinerja pada bank konvensional di Indonesia.

\section{Perbadingan Risiko dan kinerja BPR}

Ada perbedaan yang fundamental pada konsep operasional antara bank konvensional dengan bank syariah. Bank konvensional dalam beroperasi menggunakan konsep bunga pada produknya, sementara bank syariah dilarang menggunakan bunga. Dalam ajaran islam bunga adalah riba dan dilarang, sehingga bank syariah dalam beroperasi harus sesuai dengan hukum islam. Perbedaan konsep ini diduga berpengaruh terhadap risiko dan kinerja bank. Bank konvensional lebih leluasa dalam beroperasi karena semua produknya berbasis bunga, sedangkan bank syariah menggunakan konsep bagi hasil atau marjin laba. Ashraf and Rehman (2011) menemukan kinerja bank syariah kurang efektif dibanding bank 
konvensional karena menambah biaya operasi dan manajemen yang tidak efisien.

Dari sisi kinerja bank yang diukur dengan ROA, ada perbedaan yang signifikan antara kinerja BPR konvensional dengan BPR syariah. Hal ini dimungkinkn karena bankkonvensional lebih mudah dalam menjalankan aktivitasnya, sementara BPR syariah lebih rumit karena semua produk harus sesuai dengan prinsip syariah. Manajemen harus menjaga kepatuhan syariah karena operasionalnya diawasi oleh Dewan Pengawas Syariah (DPS). Risiko bank syariah lebih tinggi, karena sebagian pembiayaannya berbasis bagi hasil yang keuntungannya tergantung pada laba yang diperoleh oleh nasabah. Sementara bank konvensional mempunyai penghasilan pasti dari bunga. Kinerja BPR konvensional lebih baik karena mengahsilkan rata-rata ROA sebesar $4.08 \%$ dengan rata-rata standar kesalahan $11.53 \%$ dibanding dengan BPR syariah dengan ROA $3.00 \%$ dengan rata-rata kesalahan standar $49.10 \%$. Hasil ini sesuai dengan temuan Zeitun (2011) dan Masruki et.al (2010) yang menemukan bank syariah lebih rendah profitabilitasnya dibanding bank konvensional. Demikian pula dengan Moin (2008) dan Hanif et.al (2012) juga menemukan bank syariah kurang profitable dibanding bank konvensional.

Risiko kredit/pembiayaan mempunyai perbedaan yang signifikan antara BPR konvensional dengan syariah, dimana BPRsyariah mempunyai risiko pembiayaan yang lebih tinggi, karena rata-rata NPF sebesar 7,89\% sementara BPR konvensional hanya 3,82\%. Kondisi ini menunjukkan risiko perbankan syariah lebih tinggi dibanding bank konvensional. BPR konvensional menggunakan instrumen bunga yang mudah dipoerasional dengan risiko yang relative kecil, sementara BPR syariah menggunakan prinsip bagi hasil yang risikonya tinggi. Sebagian besar pendapatan BPR syariah ditentukan oleh keuntungan nasabahnya, sehingga jika nasabah merugi bank syariah juga akan merugi. Masruki, et al (2010) yang melakukan penelitian di Malaysia juga menemukan perbedaan yang signifikan antara risiko kredit. Bank syariah mempunyai risiko yang lebih tinggi. Demikian pula dengan Srairi (2009) yang meneliti di Negara-negara teluk dan Zeitun (2012) di Negara arab juga menemukan bank syariah lebih berisiko dibanding bank konvensional. 
Rasio kecukupan modal (CAR) secara statistik juga ada perbedaan antara BPR konvensional dengan syariah. Perbankan syariah mempunyai kecukupan modal yang sangat besar yakni ratarata sebesar $24.09 \%$ jaug lebih tinggi dibanding syarat permodalan minimum 8\%. Dari sisi kesehatan bank sangat sehat tetapi dari efisiensi penggunaan modal sangat tidak efisien. Seharusnya modal bank bisa disalurkan pada aset yang menguntungan (earning assets) untk meningkatkan keuntungan, tetapi karena tidak efisien, maka permodalannya BPR syariah banyak yang menganggur. Sementara BPR konvensional leboh efisien yang ditunjukkan dengan rata-rata CAR sebesar 19.09\%. Namun demikian, sebenarnya permodalan BPR konvensional juga kurang efisien karna masih terlalu besar. Hasil ini sesuai dengan temuan Zeitun (2011) bahwa permodalan bank konvensional lebih efisien dibanding bank syariah. Azis et.al (2016) dan Yossef dan Samir (2015) juga menemukan perbedaan antara risiko permodalan bank syarih dengan bank konvensional.

Risiko likuiditas juga berbeda secara signifikan antara BPR konvensioan dengan BPR syariah. BPR syariah lebh agresif dalam memberikan pembiayaan yang ditunjukkan dengan rata-rata FDR sebesar $96.09 \%$ dibanding BPR konvensional dengan rata-rata LDR

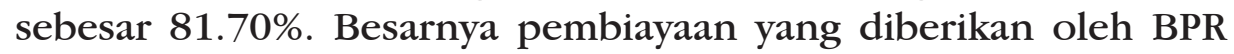
syariah seharusnya akan meningkatkan keuntungan bank, tetapi karena risiko pembiayaan (NPF) juga sangat tinggi menyebabkan profitabilitas BPR syariah lebih kecil. Sebaliknya, kredit yang diberikan oleh BPR konvensional lebih kecil tetapi karena risiko kreditnya juga kecil menjadikan profitabilitasnya lebih besar dibanding BPR syariah. Dengan demikian, selain agresivitas dalam pemberian kredit atau pembiayaan juga harus disertai dengan pengelolaan risiko kredit yang baik. Latif et.al (2016) yang melakukan penelitian di Pakistan juga menemukan LDR berbeda antara bank syariah dengan bank konvensional. Masruki et.al (2010) dan Srairi (2009) juga perbedaan risiko likuiditas tersebut.

Rasio biaya operasi dengan pendapatan operasi (BOPO) menjadi tolok ukur risiko operasional bank. BOPO secara signifikan berbedaantara BPRkonvensionaldengan BPRsyariah, dimanaBOPO BPR syariah jauh lebih kecil dibanding BPR konvensional. BOPO BPR syariah rata-rata 55.52\% sementara BPR konvensional $78.70 \%$. 
Rendahnya BOPO BPR syariah ini disebabkan dalam pemberian kompensasi baik terhadap manajemen maupun karyawan relative kecil, sehingga bisa menekan biaya operasi. Hasil ini sesuai dengan temuan Masruki (2009) bahwa bank syariah lebih efisien dari segi operasi dibanding bank konvensional. Sebaliknya Latif et.al (2016) dan Moin (2008) menemukan tidak ada perbedaan risiko operasi antara BPR konvensional dengan BPR syariah.

\section{Kesimpulan}

Berdasarkan hasil uji hipotesis, bisa disimpulkan bahwa variabel risiko kredit (NPL/NPF) bagi PRS syariah berpengaruh negatif dan signifikan tetapi bagi BPR konvensional risiko kredit berpengaruh negatif tetapi tidak signifikan. Namun juga ada variabel CAR bagi BPR konvensional berpengaruh positif dan signifikan tetapi bagi BPR syariah berpengaruh positif tetapi tidak signifikan. Hasil uji hipotesis terhadap risikolikuidtas (LDR/FDR) baikBPRkonvensional maupun BPR syariah berpengaruh positif dan signifikan terhadap kinerja (ROA) BPR. Sementara variabel risiko operasi (BOPO) juga berpengaruh signifikan tetapi negatif terhadap kinerja BPR konvensional maupun BPR syariah.

Hasil uji beda menunjukkan semua variabel yang diuji (ROA, NPL/NPF), CAR, LDR/FDR, dan BOPO) berbeda secara signifikan antara BPR konvensional dengan BPR syariah. Variabel yang lebih baik bagi BPR konvensional adalah ROA (lebih tinggi), risiko kreditnya (NPL) dan risiko likuiditas lebih rendah dibanding BPR syariah. Sementara CAR BPR syariah lebih tinggi dan BOPO BPR syariah lebih rendah dibanding BPR konvensional.

Hasil penelitian diharapkan bisa digunakan oleh manajemen baik BPR konvensional maupun BPR syariah sebagai bahan untuk pengmabilan keputusan terutama dalam meningkatkan kinerja BPR. Bagi manajer BPR syariah misalnya dari segi FDR dan BOPO sudah sangat baik tetapi NPF sangat tinggi, sehingga manajemen harus bisa mengendalikan risiko pembiayaannya (NPF) agar tidak menyebabkan penurunan keuntungan. Bagi penelitiselanjutnyabisa mengembangkan penelitian ini dengan menambah jumlah BPR, menambah variabel yang dimungkinkan juga berpengaruh terhadap kinerja BPR. 


\section{Daftar Pustaka}

Abdillah, Rahmat. Nadratuzzaman Hosen, Muhamad. dan Muhari, Syafaat Muhari. 2016. The Determinants Factor Of Islamic Bank's Profitability And Liquidity In Indonesia. Knowledge Horizons - Economics. Vol 8(2). 140-147

Agyei-Mensah, Ben K. 2012. The Impact Of Contingent Factors On

Performance Measures In The Rural Banks Of Ashanti Region

Of Ghana. International Journal of Academic Research in Business and Social Sciences. Vol. 2(8). 78-111

Ahmed, J.U dan Bhandari, G. P,. 2012. Productivity Analysis of Regional Rural Banks: A Case of Meghalaya Rural Bank. IJBMEIT, Vol 4(2). 167-178

Ahmed, J.U. Bhandari, G. P dan Ahmed, Rohima,. 2013. Profitability of regional rural banks in india: an emPirical analysis in meghalaya rural bank. Journal of Rural and Industrial Development. Vol 1(1). 1-15

Akhtar, Muhammad Farhan., Khizer Ali, and Shama Sadaqat. 2011.

Factors Influencing the Profitability of Islamic Bank of Pakistan, International Research Journal of Finance and Economics, 66, 125-132

Akhter, Waheed., Ali Raza, Orangzab, and Muhammad Akram. 2011. Efficiency and Performnace of Islamic Banking: The Case of Pakistan, Far East Journal of Psychology and Business, 2(2), 54-70

Ani, W.U., et.al., 2012. An Empirical Assessment of the Determinant on Bank Profitability in Nigeria: Bank Characteristics Panel Evodence, Journal of Accounting and Taxation, 4(3), 38-43.

Arifin, Noraini Mohd. 2012. Liquidity Risk Management and Financial Performance in Malaysia: Empirical Evidence from Islamic Banks, Aceh International Journal of Social Science, $1(2), 68-75$

Ashraf, Mian Muhammad and Zia-ur-Rehman. 2011. The Performance Analysis of Islamic and Conventional Banks: The Pakistan's Perspective. Journal of Money, Investment and Banking. Issue 22. 99-113 
Azis, Shahab. Md-Husin, Maizaitulaidawati dan Hashmi, Shujahat Haider. 2016. Performance of Islamic and Conventional Banks in Pakistan: A Comparative Study. International Journal of Economics and Financial Issues. Vol 6 (4), 1383-1391

Bukhari, Syeda Anum Javed., and Rana Abdul Qudous. 2012. Internal and External Determinant of Profitability of Banks: Evidence from Pakistan, Interdisciplinary Journal of Contemporary Research in Business, 3 (9), 1037-1058

Gul, Sehrish., Faiza Irshad, and Khalid Zaman. 2011. Factors Affecting Bank Profitability in Pakistan, The Romanian Economic Journal, 14(39), 61-87

Hallunovi, Arjeta dan Kume, Kristaq. 2016. Determinants of Profitability (ROA) in Albanian Banking System. International Scientific Conference. Belgrade. 391-400

Hanif, Muhammad., Mahvish Tariq, Arshiya Tahir, adn Wajeehul-Momeneen., 2012, Comparative Performance Study of Conventional and Islamic Banking in Pakistan, International Research Journal of Finance and Economics, 83

Latif, Youssef. Abbas, Ali, Abbas. Akram, Muhammad Nadeem. Manzoor, Shahid dan Ahmad, Saeed,. 2016. Study Of Performance Comparison Between Islamic And Conventional Banking In Pakistan. European Journal of Educational and Development Psychology. Vol 4(1). .17-33

Hanif, Muhammad. Tariq, Mahvish. Tahir, Arshiya dan Momneen Wajeeh-ul. 2012. Comparative Performance Study of Conventional and Islamic Banking in Pakistan. International Research Journal of Finance and Economics. Issue 83. 62-72

Harjanti, Ririh Sri. Mahmudah, Nurul dan Rahmadiane, Ghea Dwi,. 2016. Analisa Rasio Keuangan Pengaruhnya Terhadap Kinerja Bank Perkreditan Rakyat di Wilayah Kabupaten Tegal. Politeknik Negeri Jakarta. 502-508

Mahmud, Khaled. Mallik, Avijit. Imtiaz, Md. Farhan, dan Tabassum, Nazia,. 2016. The Bank-Specific Factors Affecting the Profitability of Commercial Banks in Bangladesh: A Panel Data Analysis, International Journal of Managerial Studies and Research (IJMSR). Vol 4 (7). 67-74 
Masruki, Rosnia., Norhazlina Ibrahim, Elmirina Osman and Hishamuddin Abdul Wahab, 2011, Financial Performance of Malaysian Founder Islamic Banks Versus Conventional Banks, Journal of Business and Policy Research, Vol. 6 (2), 67-79

Mills, Ebenezer Fiifi Emire Atta dan Amowine, Nelson,. 2013. The Rural Bank Profitability Nexus: Evidence From Ghana. International Journal of Applied or Innovation in Engineering \& Management, Vol 2(4). 507-513

Milhem, Maysa'a Munir dan Istaiteyeh, Rasha M. S, . 2015. Financial Performance Of Islamic And Conventional Banks: Evidence From Jordan. Global Journal Of Business Research. Vol 9 (3). 27-43

Pramuka, Bambang Agus., 2011-Assessing Profit Efficiency of Islamic Banks In Indonesia: An Intermediation Approach, Journal of Economics, Business and Accountancy Ventura Vol 14(1), April 2011, 79 - 88

Rachmadita, Dhea., Marsellisa Nindito, dan Nuramalia Hasanah. 2013. The Influence of Savings, Equity, Non Performing Financing and Profit Sharing on The Financing of Islamic Banks in Indonesia, International Conference on Business, Economics, and Accounting, Bangkok, Thailand

Rahman, Aulia Fuad and Ridha Rochmanika. 2012. Pengaruh Pembiayaan Jual Beli, Pembiayaan Bagi Hasil, dan Ratio Non Performance Financing terhadap Profitabilitas Bank Umum Syariah di Indonesia, ejournal.uin-malang.ac.id/index. $p h p / . . / 1768 / p d f$

Said, Rasidah Mohd dan Tumin, Mohd Hanafi,. 2011. Performance and Financial Ratios of Commercial Banks in Malaysia and China. International Review of Business Research Papers. Vol. 7 (2). 157-169

Sanwari, Suria Rismawati dan Zakaria, Roza Hazli,. 2013. The Performance Of Islamic Banks And Macroeconomic Conditions. ISRA International Journal of Islamic Finance. Vol. 5(2)

Siraj, K. K., and Sudarsanan Pillai, (2012), Comparative Study on Performance of Islamic Bank and Convensional Bank in GCC 
Region, Journal of Applied Finance and Banking, 2(3),

Srairi, Samir Abderrazek., Faccotrs Influencing the Profitability of Conventional and Islamic Banks in GCC Countries, Review of Islamic Economics, 11(1), 5-30

Sudiyatno, Bambang., (2010), Analisis Pengaruh Dana Pihak Ketiga, Bopo, Car Dan Ldr Terhadap Kinerja Keuangan Pada Sektor Perbankan Yang Go Public Di Bursa Efek Indonesia (BEI), Jurnal Dinamikan Keuangan dan Perbankan, 2(2), 125-137

Syafri. 2012. Factors Affecting Bank Profitability in Indonesia, Paper: The 2012 International Conference on Business and Management, Thailand

Vong, Anna. P.I and Hoi Sin Chan, (2011), Determinant of Bank Profitability in Macau, Working Papaer: Faculty of Business and Administration, University of Macau

Wahdan, Maydan El-Leithy, Walid,. 2017. Factors Affecting the Profitability Banks in Egypt over the Last 5 Years (2011-2015). International Business Management. Vol 11 (2). 342-349

Youssef, Amr dan Samir, Osama,. 2015. A comparative study on the financial performance between Islamic and conventional banks: Egypt case. The Business and Management Review, Vol 6(4). 161-176

Yusuf, Muhammad Yasir dan Mahriana, Wan Sri,. 2016. FaktorFaktor Yang Mempengaruhi Tingkat Profitabilitas Bank Pembiayaan Rakyat Syariah (BPRS) Di Aceh . Iqtishadia. Vol 9 (2). 246-275

Zeitun, Rami. 2012. Determinant of Islamic and Conventional Banks Performance ini GCC Countries Using Panel data Analysis, Global Econony and Finance Journal, 5 (1), 53-72 